\title{
Checking on Preferential Choices of E-learning \& M- learning: A Case Study of Northern Border University, Saudi Arabia
}

https://doi.org/10.3991/ijet.v12i05.6790

Ahmed Alenezi

Northern Border University, Arar, Saudi Arabia

alenezi8@yahoo.com

\begin{abstract}
The development of new E-learning technologies and the arrival of mobile learning systems have brought greater impact on the education sector especially towards higher education learning system. There is no doubt that it is extremely useful for all those individuals lacking sufficient time for their studies. They can use such electronic forms of learning to enjoy the anytime $\&$ anywhere learning environment. It has attracted the attention of big software industry owners as well as mobile technology based companies over the period. M-learning is able to provide the learners with learning opportunities with greater capabilities through the use of mobile phones or smart-phones. Northern Border University (NBU) in Saudi Arabia is already using several online and offline automated software's \& Blackboard LMSs in its various Deanships, Colleges and Departments for student's self-learning purposes. This case study aims to assess the behavioral differences of students/faculty members using Elearning (Mobile Apps/Web applications) to learn/teach the respective subjects. It discusses about the perceptions of students/faculty members about Mlearning \& E-learning including the modes and their maximum uses of certain mobile App/Web Application whether offline or online. There are five criteria and for each criterion questionnaires are designed to take the opinions from different groups. Likert scale method is used here. Statistical testing method TTest is used here to calculate the results among the groups.
\end{abstract}

Keywords-Blackboard, E-learning, M-learning, Mobile Phone, Web Applications

\section{$1 \quad$ Introduction}

In this era of Internet learning is thoroughly multilateral and a flexible option. It can be used anytime and anywhere as per user requirements. It increases the interactivity levels in learning processes. Learning materials can be shared easily. At the same time thousands of students and teachers might use it without any reservation of limitations. They can share their views, store \& download their study materials through mere having Internet connection. Such facilities are making E-learning (learning conducted via electronic media, typically on the internet) popular each pass- 
ing of the day. It has already become an important part of modern education today. That's why now-a-days most of the universities are providing E-learning platforms besides regular education system to their students. It is helpful to improve the quality of education and to provide education to all those people who are willing to obtain education but can't attend traditional university education system due to time constraints and professional or personal preoccupations. A study shows that $97 \%$ students in Saudi Arabia are fully equipped with personal computers and very steady internet connection [3].

According to a study conducted by Madar, e-learning in Saudi Arabia is projected to grow and reach up to $\$ 125$ in 2008 and is set to rise at the annual rate of $33 \%$ in the next five years. This is driven by the initiatives taken by the Ministry of Education for the integration of ICT (Information \& Communication Technology) in educational sector. In an initiative to create profile of Arabian internet users by Harvard University in 2008 and 2009, entailed that the gap between male and female population is decreasing and most of the users are between the age group of 35 to 25 . The data suggests that there is very conducive environment for e-learning industry to grow and flourish in the coming future. The government in Saudi Arabia has taken many sincere steps to improve the education system of its country in the last one decade. Its outcome can be best observed through witnessing this reality that every university run by the Ministry of Education has already implemented E-learning systems. Even several private universities in this country have either implemented or are on the verge of implementing LMSs to propagate this advanced education system.

\subsection{Objective of the Study}

Following are the objectives of this study:

- To shed light on the concept of E-learning and M-learning.

- To compare the popularity between E-learning \& M-learning in overall population of university.

- To compare the preferential choices between E-learning and m learning between students, male \& female faculty members.

- Researchers have tested each criterion by taking opinion from the population. To obtain this researcher separately calculated the mean of each set (criterion).

\section{$2 \quad$ Literature Review}

Both E-learning (learning conducted via electronic media, typically on the internet) and M-learning (learning across multiple contexts, through social and content interactions, using personal electronic devices) are integral parts of Educational Technology. They are focused on the electronic learning system offered via Internet. In the nutshell, most universities in the worldwide locations are already using the electronic learning concept to support students whether they are enrolled in the regular mode or in the distance mode of education. It includes text, audio, video satellite and anima- 
tion etc. According to S. Alexander [23] and F. Mikic \& L. Anido [4], E-learning could be defined as a concept that refers to the use of computer networks and machines in the learning process. Both E-learning \& M-learning modes can be synchronous or asynchronous, instructor based or self-based learning.

\subsection{E-learning}

E-learning is a software solution to ease education system. Internet use in the higher education has grown exponentially in the recent years [1], [26]. E-learning transfers the knowledge and skills through the use of electronic processes and applications for learning [16], [9]. Fry [5] envisaged for the institutions of higher learning especially universities to survive, retain positions and excel in the global education marketplace by taking certain extensive initiatives including the most important one of adopting the modern technological tools which are in line to the overall progress of technology. Undoubtedly, such steps would prove a boon to revolutionize educational pursuits. Several universities, therefore, prefer specific LMSs to boost their online education pursuits besides fulfilling their database related needs. In 2013, NBU implemented Blackboard LMS in its campuses as an E-learning solution. The solution proved highly effective since designing and implementation phase of various courses and with the overall support through classroom trainings \& facilitating associated tools. According to Georgouli, Skalkidis, \& Guerreiro, LMS provided a reliable E-learning infrastructure approach. It has given a standard E-learning platform which is fulfilling the requirements recommended by the educational and commercial shareholders in the emerging E-learning market [8].

According to Jain K.K. \& Ngoh B.L., [15] the flexibilities which E-learning offers to students is the main motivating factor in choose the online courses. E-learning is a learning model which can supplement the traditional classroom model and is capable to offer a kind of education with less space or tightness schedule [13], [28]. Elearning has this potentiality to impact positively on the educational pursuits. It provides great opportunities for both educators and the learners to enrich their educational experiences [2].

\subsection{Mobile Learning}

Education sector is welcoming fast transformations with constant changes and improvements in the mobile applications and their easy integration into E-learning systems. Notable amongst all, the advantages include thorough support in the assessments and reporting on multiple platforms in ease which otherwise make it hassle-free to receive or send feedbacks. Such interactivity is definitely crucial in education management. Absence of such technological tools often proved hindrances for several institutions facing unnecessary delays in the report generations of student performances. Such limitations would often directly cause hindrance in taking some rapid decisions to assess the performances. Both institutions and parents of enrolled students would equally suffer due to the unavoidable delays. 
It is an undeniable fact that with the widespread increase and changes in mobile technologies, both students and faculty members are bound to use portable devices [27]. Growing use of mobiles has also influenced the academic researchers as well as practitioners to incorporate best suitable technological tools in their learning environments to receive timely and effective outcomes. As per the report of Mary Meeker and R. Lawler [19] there is fast migration to mobile devices due to increase in the Mobile Internet trends, henceforth, maximum number of PC client software is already migrating to that [14]. Likewise, as per the statistical prediction of Gartner [7], total downloads of mobile apps till 2013 had already reached up to approximately 81 billion which was worth noticing. The same research found out that out of total numbers approximately 800,000 Android apps were in the Google Play market itself while the total download went to approximately 48 billion by May 2013 which was marked as a revolutionary trend (http://en.wikipedia.org/wiki/List, 2013).

The concept of effective teaching techniques has changed drastically with the wider use of various types of educational media and technological tools. They play pivotal roles to promote literacy and learning environments amongst the learners especially children willing to attain education in either formal or informal environments [20].

Connolly and Stansfield [1] summarized the development of e-learning studies in three distinct phases. The first phase i.e. early nineties through the late nineties marked a passive use of internet where traditional materials were simply repurposed to an online format. Mostly the resources were digitized in order to have easy access to the materials available across the globe. The second phase i.e. the early years of the last decade marked a transition with higher band-widths, increased resources and a strong desire to create virtual learning environments that facilitated access to course materials, communications and students' services. The third phase is currently running with greater collaborations, reflective practices, online simulations, project based learning in the background of knowledge resources like, wikis, blogs, e-portfolios etc. The current generation is immensely influenced by the advances in mobile technology that has empowered them to have easy and reliable access to the riches of resources. It is quite obvious in the present scenario that technology has completely transformed the teaching/learning process. It has redefined the educational purposes and methods. Right from communication evolution to rapid/random access to information and also to collaborative learning, technology has influenced the educational process to the extent that the theorists have proposed new learning theories such as rizomatic learning, Connectivism, heutagogy, paragogy, etc [22].

Concern regarding user acceptance of new technology, is considered to be the most desired areas in information system literature [22]. Eventually researches in this area have resulted in several theoretical models with their bases in psychology, sociology or information systems which have dealt in users' intention to use technology [22]. Technology Acceptance Model (TAM) as proposed by Davis, Bagozzi and Warsaw [22], incorporated usefulness and ease of use as the possible dominant factors when users make choices of technologies. David, Morris and Venkatesh [22] revisited the TAM model and seven other models and proposed that Unified Theory of Acceptance and Use of Technology (UTAUT) which posits three direct determinants of intention to use (performance expectancy, effort expectancy, and social influence) and two 
direct determinants of usage behavior (intention and facilitating conditions). Roger's innovation theory [21] proposed that innovation that can influence adoption of technology in teaching/learning process. The factors like; Compatibility (degree of consistency with the values, habits and experiences of the users), relative advantage (the degree of the advantages in comparison to the comparable products) and complexity (degree of how user-friendly it is for the users) are the bases for perception in making the choices among the available technology. However, all these variables were taken into account in having a comprehensive view on the perception of the students and the staff of the university in the present study.

Lorenzi and Riley [18] observed that the main success to system success is behavioral, rather than technical. Gamal \& El Aziz [6] suggested that e-learning or technology based learning is not perceived as a reliable source. Possible reason for this is that the users have not been fully aware of its benefits and the readiness for the same among the Egyptian students is still a mark to be achieved. Attitude of the end user towards the viability and suitability of the tools of information technology is one of the major factors concerning successful implementation in the academic programs. In recent years, the studies conducted to explore the students' perception have shown a growing trend in the acceptance of new technology wherever technology has permeated to the very basic necessity of their lives. This trend is quite impressive in the developed and economically advanced or high income level countries where the infrastructure and resources are readily available for various stakeholders. The studies in Australia, the UK and in the US have shown that the students have fair access to web-enabled computers and web features or the same in their own personal devices [22]. Vast majority of students use web and wide range o f digital features in their day to day lives in order to form social networking and in referring to web resources in their academic activities. However, the trend is quite different in the developing or under developed countries. Access to digital world is getting popular but the use of digital media in teaching/learning process is still dream to put into reality.

The following are the key differences between E-learning and M-learning:

Table 1. Key Differences between E-learning \& M-learning

\begin{tabular}{|c|l|l|}
\hline SL No. & \multicolumn{1}{|c|}{ E Learning } & \multicolumn{1}{c|}{ M Learning } \\
\hline 1. & $\begin{array}{l}\text { E-learning can be accessed from fixed wired } \\
\text { devices }\end{array}$ & It can be used anytime and anywhere \\
\hline 2. & Needs High speed internet connectivity & Low internet speed as compared to e- learning \\
\hline 3. & Big screen size & Small screen size \\
\hline 4. & It needs proper infrastructure & It doesn't need infrastructure \\
\hline 5. & Complex in graphics & $\begin{array}{l}\text { Not too much complex graphics as compared e- } \\
\text { learning }\end{array}$ \\
\hline
\end{tabular}

\section{Methodology}

In this case study that has been conducted in the NBU campus, with the aim to learn the perceptions of university students about their use of E-learning and M- 
learning applications. The study was conducted on the regular students (full time students) of NBU. They are already using several E-learning software and mobile apps. Such facilities have been made available free of cost for the students, faculty \& staff such as the Preparatory Year \& English Language Skills, facilitating free Rosetta stone to students learning English language. This university has state of the art computer labs for the students to practice this special Software. Moreover, Rosetta stone mobile version is also available for them to practice as and when they like. NBU has already installed Blackboard: Learning Management System (Blackboard LMS, hereafter) to support its E-learning \& M-learning education system. Blackboard mobile version is also available for all concerned. All academics related tasks have shifted or are on the verge of shifting onto the Blackboard such as taking the quizzes or assignments through the Blackboard LMS.

In this case study, researchers designed questionnaire (Appendix) to take opinions from population. The questionnaire is further divided into 5 criteria; time duration, user satisfaction, user friendly, connectivity, benefits of E-learning \& M-learning. For each criterion there are particular questions for E-learning and M-learning both. The whole population was also divided into 3 groups; student group, male faculty group, female faculty group. Researcher performed T- Test to extract the result of this case study.

\subsection{Questionnaire Design}

To confirm that no important items were left, surveys \& interviews were conducted with the help of department academic staff. We sent our questionnaire to three professors whose interest area is electronic learning and education for review. They were asked to review the initial item list of questionnaires; they recommended eliminating six questions because those questions were not suitable for our survey. After careful examination of the result of the surveys and interviews, the revised 34 questions were further adjusted to make their wording as precise as possible so as to be considered to constitute a complete scale for successful measurement. In these 34 questions, there are two parts (17 questions for e-learning \& same 17 Question were asked for mlearning) for each category. The present research is a study based on students as well as the teachers views on their preference of using E-Learning or M-learning tools. It involves non-sensitive survey and interview procedures of the participants wherein there is no psychological stress or anxiety caused to assert their opinion. This study is purely a survey based wherein names and photographs have not been mentioned anywhere that could place them at any sort of risk. It aims to seek their opinions in order to implement proper and most viable technological tools in their teaching/learning process.

An initial questionnaire having 34 items with the five criteria measures was developed using five points Likert-type scale. The five criteria measures are: 1. Time duration; 2. User satisfaction; 3.User friendly; 4.Connectivity 5 . Benefits of e-learning \& m-learning were used to analyze the criterion-related validity of the instrument and to measure the overall e-learning \& m-learning systems success prior to detailed analysis. Respondents were required to rate the items in the scale based on 5 points Likert 
scale with end point of '5' Strongly Agree, '4' Agree, '3' Neutral , '2' Disagree '1' Strongly Disagree.

Table 2. Number of Questions as per their Criteria

\begin{tabular}{|l|l|l|}
\hline \multicolumn{1}{|c|}{ SET No. } & \multicolumn{1}{c|}{ Question No's } & \multicolumn{1}{c|}{ Criteria measure } \\
\hline SET 1 & Question 1 to 4 & Time Duration \\
\hline SET 2 & Question 5 to 16 & User Satisfaction \\
\hline SET 3 & Question 17 to 20 & User Friendly \\
\hline SET 4 & Question 21 to 26 & Connectivity \\
\hline SET 5 & Question 27 to 34 & Benefits of e \& m Learning \\
\hline
\end{tabular}

\subsection{Sample Selection}

Our department already trained 976 male faculty, 1133 female faculty \& 4485 students (including male \& female) in 152 workshops which were held for e-learning \& m-learning. Sekaran (2000) Stated "samples size larger than 65 and less than 500 are appropriate for most research". Here, the random selection of population in this survey was of 570. We received correct information from 501 participants out of total 570. Some forms were not filled properly; hence, they had to be rejected from the survey data. Out of 501 participants 204 were students, 168 female faculty \& 129 male faculty members.

Table 3. No. of Samples Taken From Each Group

\begin{tabular}{cccc}
\hline $\begin{array}{c}\text { Male Faculty } \\
\text { population }\end{array}$ & $\begin{array}{c}\text { Female Faculty } \\
\text { Population }\end{array}$ & $\begin{array}{c}\text { Student } \\
\text { Population }\end{array}$ & $\begin{array}{c}\text { Total Popula- } \\
\text { tion }\end{array}$ \\
129 & 168 & 204 & 501 \\
\hline
\end{tabular}

The method to conduct the survey was of mixed environment. First, through the printed papers after face to face discussion \& second method was through the emails sent for online surveys. In the last statistical calculations were performed from the answers which we collected through both online and offline modes.

The student/faculty members at NBU are already using various types of E- learning and M-learning tools for the study purposes and for the rest information such as examination announcements and also to check the results etc. There were three types of tests for that purpose which we conducted to find out the results.

\subsection{Research Hypotheses}

The validity of current research can be checked on the following hypotheses:

There is a statistically significant difference at the level $(0.05)$ between the mean scores of the performance of the experimental group as a whole.

- First: male population learning preference (M-learning or E-learning).

- Second: female faculty members' preference. 
- Third: students' preference on m-learning or e-learning

- Fourth: overall population's preference (student, male \& female faculty members)

- After the above 4 test results which choice is dominant whether it is m-learning or e- learning, we tested the difference of male \& female faculty members' dominant choices.

- Researcher also observed that in overall population (student, male \& female faculty group) opinion were different based on 5 criteria. So, researcher already calculated the average (mean) of each sets first. Then researcher found that in all SET's mean of m-learning was higher except SET 2 (User Satisfaction Criterion). SET 2 was calculated separately to evaluate the difference.

\section{$4 \quad$ Data Calculation \& Result}

\subsection{Test the Validity of the First Hypothesis}

Table 4. Male Data

\begin{tabular}{|l|c|c|}
\hline \multicolumn{1}{|c|}{ Questionnaires set no. } & M-learning & E-learning \\
\hline SET 1 Mean score & 3.609375 & 2.75969 \\
\hline SET 2 Mean score & 2.8888 & 3.47753 \\
\hline SET 3 Mean score & 3.895349 & 2.64728 \\
\hline SET 4 Mean score & 3.356589 & 3.049095 \\
\hline SET 5 Mean score & 3.79845 & 3.30093 \\
\hline Total Mean of group & 3.509712 & 3.046905 \\
\hline
\end{tabular}

The researcher performed ( $\mathrm{t}$-test) for independent samples to find out the difference between the overall means of m-learning \& e-learning in male faculty group.

\section{Hypothesis}

$\mathrm{H}_{\mathrm{m} \text { Learning male }}=\mathrm{H}_{\mathrm{e} \text { Learning male }}$ There is no difference between these two groups

$\mathrm{H}_{\mathrm{m} \text { Learning male }} \neq \mathrm{H}_{\mathrm{e} \text { Learning male }}$ There is significant difference between these two groups

\section{Difference Scores Calculations}

\begin{tabular}{l|l}
\hline \multicolumn{1}{c|}{ Treatment 1 } & \multicolumn{1}{c}{ Treatment 2 } \\
\hline $\mathrm{N}_{1}: 5$ & $\mathrm{~N}_{2}: 5$ \\
\hline $\mathrm{df}_{1}=\mathrm{N}-1=5-1=4$ & $\mathrm{df}_{2}=\mathrm{N}-1=5-1=4$ \\
\hline $\mathrm{M}_{1}: 3.51$ & $\mathrm{M}_{2}: 3.05$ \\
\hline $\mathrm{SS}_{1}: 0.65$ & $\mathrm{SS}_{2}: 0.49$ \\
\hline $\mathrm{S}_{1}{ }_{1}=\mathrm{SS}_{1} /(\mathrm{N}-1)=0.65 /(5-1)=0.16$ & $\mathrm{~s}_{2}=\mathrm{SS}_{2} /(\mathrm{N}-1)=0.49 /(5-1)=0.12$ \\
\hline
\end{tabular}




\section{T-value Calculation}

$s_{p}^{2}=\left(\left(d f_{1} /\left(d f_{1}+d f_{2}\right)\right) * s^{2}{ }_{1}\right)+\left(\left(d f_{2} /\left(d f_{2}+d f_{2}\right)\right) * s_{2}^{2}\right)=((4 / 8) * 0.16)+((4 / 8) * 0.12)=$ 0.14

$$
\begin{aligned}
& s^{2}{ }_{M 1}=s_{p}^{2} / N_{1}=0.14 / 5=0.03 \\
& s^{2}{ }_{M 2}=s^{2}{ }_{p} / N_{2}=0.14 / 5=0.03 \\
& \quad t=\left(M_{1}-M_{2}\right) / \sqrt{ }\left(s^{2}{ }_{M 1}+s^{2}{ }_{M 2}\right)=0.46 / \sqrt{ } 0.06=1.94
\end{aligned}
$$

The $t$-value is 1.93581 . The $p$-value is .04446. The result is significant at $p<.05$.

Hence, $\mathrm{H}_{\text {m Learning male }} \neq \mathrm{H}_{\mathrm{e} \text { Learning male }}$

There is a significant difference between these two groups:

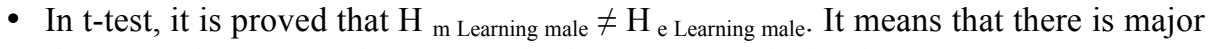
difference between m-learning and e-learning in male faculty group.

- Hence, it is proved in the second test that maximum male population choice is $\mathrm{m}$ Learning (mobile devices) than e-learning.

\subsection{Test the Validity of the Second Hypothesis}

Table 5. Female Data

\begin{tabular}{lcc}
\hline \multicolumn{1}{c}{ Questionnaires set no. } & M-learning & E-learning \\
SET 1 Mean score & 3.714935 & 2.726905 \\
SET 2 Mean score & 3.164683 & 3.877968 \\
SET 3 Mean score & 4.241071 & 2.741072 \\
SET 4 Mean score & 3.577381 & 3.121032 \\
SET 5 Mean score & 3.75744 & 3.199405 \\
Total Mean of group & 3.691102 & 3.133276 \\
\hline
\end{tabular}

\section{Hypothesis}

$\mathrm{H}_{\mathrm{m} \text { Learning female }}=\mathrm{H}_{\mathrm{e} \text { Learning female }}$ There is no difference between these two groups

$\mathrm{H}_{\mathrm{m} \text { Learning female }} \neq \mathrm{H}_{\mathrm{e} \text { Learning female }}$ There is significant difference between these two group

\section{Difference Scores Calculations}

\begin{tabular}{l|l}
\hline \multicolumn{1}{c|}{ Treatment 1 } & \multicolumn{1}{c}{ Treatment 2 } \\
\hline$N_{1}: 5$ & $N_{2}: 5$ \\
\hline$d f_{1}=N-1=5-1=4$ & $d f_{2}=N-1=5-1=4$ \\
\hline$M_{1}: 3.69$ & $M_{2}: 3.13$ \\
\hline$S S_{1}: 0.6$ & $S S_{2}: 0.88$ \\
\hline$S_{1}{ }_{1}=S S_{1} /(N-1)=0.6 /(5-1)=0.15$ & $S^{2}{ }_{2}=S S_{2} /(N-1)=0.88 /(5-1)=0.22$ \\
\hline
\end{tabular}




\section{T-value Calculation}

$s_{p}^{2}=\left(\left(d f_{1} /\left(d f_{1}+d f_{2}\right)\right) * s^{2}{ }_{1}\right)+\left(\left(d f_{2} /\left(d f_{2}+d f_{2}\right)\right) * s_{2}{ }_{2}\right)=((4 / 8) * 0.15)+((4 / 8) * 0.22)=$ 0.18

$s_{M 1}^{2}=s_{p}^{2} / N_{1}=0.18 / 5=0.04$

$s_{M 2}^{2}=s_{p}^{2} / N_{2}=0.18 / 5=0.04$

$t=\left(M_{1}-M_{2}\right) / \sqrt{ }\left(s_{M 1}^{2}+s^{2}{ }_{M 2}\right)=0.56 / \sqrt{ } 0.07=2.05$

The $t$-value is 2.05371. The $p$-value is .03704 . The result is significant at $p<.05$.

Hence $\mathrm{H}_{\mathrm{m} \text { Learning female } \_} \neq \mathrm{H}_{\mathrm{m} \text { Learning female }}$ There is a significant difference between these two groups.

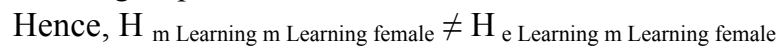

There is a significant difference between these two groups:

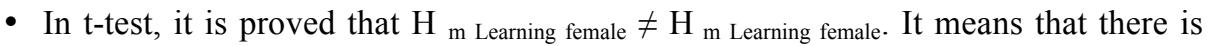
major difference between m-learning and e-learning in female faculty group.

- Hence, it is proved in the first test that maximum female population choice is $\mathrm{m}$ learning (mobile devices) than e-learning.

\subsection{Test the Validity of the Third Hypothesis}

Table 6. Student Data

\begin{tabular}{lcc}
\hline \multicolumn{1}{c}{ Questionnaires set no. } & M-learning & E-learning \\
SET 1 Mean score & 4.117647 & 2.813726 \\
SET 2 Mean score & 3.02941 & 3.938726 \\
SET 3 Mean score & 4.28431 & 2.6298 \\
SET 4 Mean score & 3.656863 & 3.07516 \\
SET 5 Mean score & 4.090686 & 3.112745 \\
Total Mean of group & 3.835783 & 3.114031 \\
\hline
\end{tabular}

\section{Hypothesis}

$\mathrm{H}_{\mathrm{m} \text { Learning student }}=\mathrm{H}_{\mathrm{e} \text { Learning student }}$ there is no difference between these two groups

$\mathrm{H}_{\mathrm{m} \text { Learning student }} \neq \mathrm{H}_{\mathrm{e} \text { Learning student }}$ there is significant difference between these two groups 


\section{Difference Scores Calculations}

\begin{tabular}{l|l}
\hline \multicolumn{1}{c|}{ Treatment 1 } & \multicolumn{1}{c}{ Treatment 2 } \\
\hline$N_{1}: 5$ & $N_{2}: 5$ \\
\hline$d f_{1}=N-1=5-1=4$ & $d f_{2}=N-1=5-1=4$ \\
\hline$M_{1}: 3.84$ & $M_{2}: 3.11$ \\
\hline$S S_{1}: 1.03$ & $S S_{2}: 1.01$ \\
\hline$s_{1}{ }_{1}=S S_{1} /(N-1)=1.03 /(5-1)=0.26$ & $s_{2}{ }_{2}=S S_{2} /(N-1)=1.01 /(5-1)=0.25$ \\
\hline
\end{tabular}

\section{T-value Calculation}

$$
\begin{aligned}
& s_{p}^{2}=\left(\left(d f_{1} /\left(d f_{1}+d f_{2}\right)\right) * s_{1}^{2}\right)+\left(\left(d f_{2} /\left(d f_{2}+d f_{2}\right)\right) * s_{2}^{2}\right)=((4 / 8) * 0.26)+((4 / 8) * 0.25)= \\
& 0.25 \\
& s_{M 1}^{2}=s_{p}^{2} / N_{1}=0.25 / 5=0.05 \\
& \quad s_{M 2}^{2}=s_{p}^{2} / N_{2}=0.25 / 5=0.05 \\
& \quad t=\left(M_{1}-M_{2}\right) / \sqrt{ }\left(s_{M 1}^{2}+s_{M 2}^{2}\right)=0.72 / \sqrt{ } 0.1=2.26
\end{aligned}
$$

The $t$-value is 2.26314. The $p$-value is .02673 . The result is significant at $p<.05$.

Hence $\mathrm{H} 1$ m Learning student_ $\neq \mathrm{H} 2 \mathrm{~m}$ Learning student There is a significant difference between these two groups

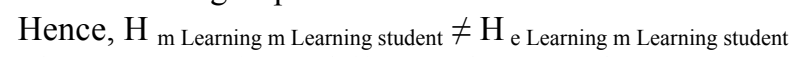

There is a significant difference between these two groups:

- In t-test, it is proved that $\mathrm{H}_{\mathrm{m} \text { Learning student }} \neq \mathrm{H}_{\mathrm{m} \text { Learning student }}$. It means that there is major difference between m-learning and e-learning in female faculty group.

- Hence, it is proved in the test that maximum student population choice is $\mathrm{m}$ learning (mobile devices) than e-learning.

\subsection{Test the Validity of the Fourth Hypothesis}

Table 7. Total Population Data (Male Faculty + Female Faculty + Student)

\begin{tabular}{lcc}
\hline \multicolumn{1}{c}{ Questionnaires set no. } & M-learning & E-learning \\
SET 1 Mean score & 3.854131 & 2.7704 \\
SET 2 Mean score & 2.999667 & 3.810313 \\
SET 3 Mean score & 4.023953 & 2.67165 \\
SET 4 Mean score & 3.552894 & 3.083832 \\
SET 5 Mean score & 3.903692 & 3.191118 \\
Total Mean of group & 3.666867 & 3.105463 \\
\hline
\end{tabular}

\section{Hypothesis}

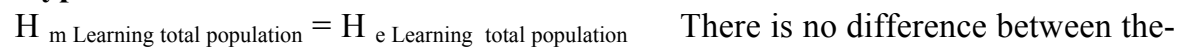
se two groups 


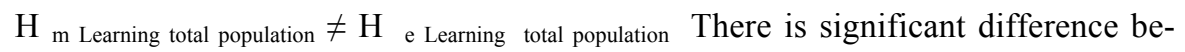
tween these two group

\section{Difference Scores Calculations}

\begin{tabular}{l|l}
\hline \multicolumn{1}{c|}{ Treatment 1 } & \multicolumn{1}{c}{ Treatment 2 } \\
\hline$N_{1}: 5$ & $N_{2}: 5$ \\
\hline$d f_{1}=N-1=5-1=4$ & $d f_{2}=N-1=5-1=4$ \\
\hline$M_{1}: 3.67$ & $M_{2}: 3.11$ \\
\hline$S S_{1}: 0.68$ & $S S_{2}: 0.81$ \\
\hline$S_{1}{ }_{1}=S S_{1} /(N-1)=0.68 /(5-1)=0.17$ & $S^{2}{ }_{2}=S S_{2} /(N-1)=0.81 /(5-1)=0.2$ \\
\hline
\end{tabular}

\section{T-value Calculation}

$$
\begin{aligned}
& \quad s_{p}^{2}=\left(\left(d f_{1} /\left(d f_{1}+d f_{2}\right)\right) * s_{1}^{2}\right)+\left(\left(d f_{2} /\left(d f_{2}+d f_{2}\right)\right) * s_{2}^{2}\right)=((4 / 8) * 0.17)+((4 / 8) * 0.2) \\
& =0.19 \\
& s_{M 1}^{2}=s_{p}^{2} / N_{1}=0.19 / 5=0.04 \\
& \quad s_{M 2}^{2}=s_{p}^{2} / N_{2}=0.19 / 5=0.04 \\
& \quad t=\left(M_{1}-M_{2}\right) / \sqrt{ }\left(s_{M 1}^{2}+s_{M 2}^{2}\right)=0.56 / \sqrt{ } 0.07=2.06
\end{aligned}
$$

The $t$-value is 2.06245. The $p$-value is .036541. The result is significant at $p<.05$.

Hence $\mathrm{H}_{\mathrm{m} \text { Learning total population_} \_} \neq \mathrm{H}_{\mathrm{e} \text { Learning total population }}$

There is a significant difference between these two groups:

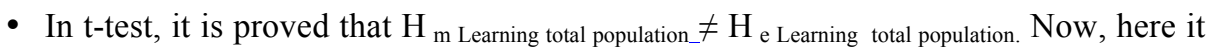
is clear that there is a significant difference between m-learning \& e-learning.

- Hence, it is proved in the test that maximum people choice is m-learning.

\subsection{Test the Validity of the Fifth Hypothesis}

Table 8. Mobile Male and Female Faculty Data

\begin{tabular}{lcc}
\hline \multicolumn{1}{c}{ Questionnaires set no. } & M-learning & M-learning \\
SET 1 Mean score & 3.609375 & 3.714935 \\
SET 2 Mean score & 2.8888 & 3.164683 \\
SET 3 Mean score & 3.895349 & 4.241071 \\
SET 4 Mean score & 3.356589 & 3.577381 \\
SET 5 Mean score & 3.79845 & 3.75744 \\
Total Mean of group & 3.509712 & 3.691102 \\
\hline
\end{tabular}




\section{Hypothesis}

$\mathrm{H}_{\mathrm{m} \text { Learning male\&female }}=\mathrm{H}_{\mathrm{e} \text { Learning male\&female }}$ There is no difference between these two groups

$\mathrm{H}_{\mathrm{m} \text { Learning male\&female }} \neq \mathrm{H}$ e Learning male\&female There is significant difference between these two group

\section{Difference Scores Calculations}

\begin{tabular}{l|l}
\hline \multicolumn{1}{c|}{ Treatment 1 } & \multicolumn{1}{c}{ Treatment 2 } \\
\hline$N_{1}: 5$ & $N_{2}: 5$ \\
\hline$d f_{1}=N-1=5-1=4$ & $d f_{2}=N-1=5-1=4$ \\
\hline$M_{1}: 3.51$ & $M_{2}: 3.69$ \\
\hline$S S_{1}: 0.65$ & $S S_{2}: 0.6$ \\
\hline$s_{1}{ }_{1}=S S_{1} /(N-1)=0.65 /(5-1)=0.16$ & $s^{2}{ }_{2}=S S_{2} /(N-1)=0.6 /(5-1)=0.15$ \\
\hline
\end{tabular}

\section{T-value Calculation}

$s_{p}^{2}=\left(\left(d f_{1} /\left(d f_{1}+d f_{2}\right)\right) * s^{2}{ }_{1}\right)+\left(\left(d f_{2} /\left(d f_{2}+d f_{2}\right)\right) * s_{2}{ }_{2}\right)=((4 / 8) * 0.16)+((4 / 8) * 0.15)=$ 0.16

$$
\begin{aligned}
& s_{M 1}^{2}=s_{p}^{2} / N_{1}=0.16 / 5=0.03 \\
& s_{M 2}^{2}=s_{p}^{2} / N_{2}=0.16 / 5=0.03 \\
& t=\left(M_{1}-M_{2}\right) / \sqrt{ }\left(s_{M 1}{ }_{M 1}+s_{M 2}^{2}\right)=-0.18 / \sqrt{ } 0.06=-0.73
\end{aligned}
$$

The $t$-value is -0.726 . The $p$-value is .244266 . The result is not significant at $p<$ .05 .

Hence $\mathrm{H}_{\text {male\&female }}=\mathrm{H}_{\text {male\&female }}$ There is a no significant difference between these two groups:

- In t-test, it is proved that $\mathrm{H}_{\text {male\&female }}=\mathrm{H} 2$ male\&female. It means that there is no major difference between male and female faculty group in using $m$ Learning.

- Hence, it is proved in the test those male and female faculties are using m-learning devices but there is no difference in their m-learning groups in terms of usability of

\begin{tabular}{|c|c|c|}
\hline \multicolumn{3}{|c|}{ SET 2 (User Satisfaction Data) } \\
\hline Questionnaires set no. & M-learning & E-learning \\
\hline Male SET 2 Mean score & 2.8888 & 3.47753 \\
\hline Female SET 2 Mean score & 3.164683 & 3.877968 \\
\hline Student SET 2 Mean score & 3.02941 & 3.938726 \\
\hline Total Mean of group & 3.027631 & 3.764741 \\
\hline
\end{tabular}
m-learning devices.

\subsection{Test the Validity of the Sixth Hypothesis}




\section{Hypothesis}

$\mathrm{H} 1=\mathrm{H} 2$ : There is no difference between these two groups

$\mathrm{H} 1 \neq \mathrm{H} 2$ : There is significant difference between these two groups

\section{Difference Scores Calculations}

\begin{tabular}{l|l}
\hline \multicolumn{1}{c|}{ Treatment 1 } & \multicolumn{1}{c}{ Treatment 2 } \\
\hline $\mathrm{N} 1: 3$ & $\mathrm{~N} 2: 3$ \\
\hline $\mathrm{df} 1=\mathrm{N}-1=3-1=2$ & $\mathrm{df2}=\mathrm{N}-1=3-1=2$ \\
\hline $\mathrm{M} 1: 3.03$ & $\mathrm{M} 2: 3.76$ \\
\hline $\mathrm{SS} 1: 0.04$ & $\mathrm{SS} 2: 0.13$ \\
\hline $\mathrm{s} 21=\mathrm{SS} 1 /(\mathrm{N}-1)=0.04 /(3-1)=0.02$ & $\mathrm{~s} 22=\mathrm{SS} 2 /(\mathrm{N}-1)=0.13 /(3-1)=0.06$ \\
\hline
\end{tabular}

\section{T-value Calculation}

$\mathrm{s} 2 \mathrm{p}=((\mathrm{df} 1 /(\mathrm{df} 1+\mathrm{df} 2)) * \mathrm{~s} 21)+((\mathrm{df} 2 /(\mathrm{df} 2+\mathrm{df} 2)) * \mathrm{~s} 22)=((2 / 4) * 0.02)+((2 / 4)$

$* 0.06)=0.04$

$\mathrm{s} 2 \mathrm{M} 1=\mathrm{s} 2 \mathrm{p} / \mathrm{N} 1=0.04 / 3=0.01$

$\mathrm{s} 2 \mathrm{M} 2=\mathrm{s} 2 \mathrm{p} / \mathrm{N} 2=0.04 / 3=0.01$

$\mathrm{t}=(\mathrm{M} 1-\mathrm{M} 2) / \sqrt{ }(\mathrm{s} 2 \mathrm{M} 1+\mathrm{s} 2 \mathrm{M} 2)=-0.74 / \sqrt{ } 0.03=-4.4$

The $\mathrm{t}$-value is -4.46336 . The $\mathrm{p}$-value is .005566 . The result is significant at $\mathrm{p}<.05$. Hence $\mathrm{H} 1 \_\mathrm{H} 2$ : There is a significant difference between these two groups:

- In the $\mathrm{t}$ test it is proved that $\mathrm{H} 1 \neq \neq \mathrm{H} 2$. It means that e learning is better choice for user satisfaction criterion.

- Hence, it means that maximum user want to use e-learning for content making, quizzes and announcements.

\section{Generalization of the Results}

1. After getting the results from above tests we can say that in recent trends people are using more m-learning devices for study purpose as compared to e-learning. They feel easy to work on mobile devices because it gives them flexibility to work from anywhere and anytime. They can contact each other for solution via chatting or video-conferencing.

2. There is no major difference between male \& female faculty preferences. Both group preferred mobile learning.

3. M-learning devices are small in screen size that's why users prefer e-learning devices to create content.

Several studies have been published in recent years, assessing the students' perception and their expectation regarding e-learning [27]. The statistics proposed by National Center for Education shows that there is a growing demand and acceptance of 
online learning [22] and the students are responding positively about their experiences with e-learning. Keller and Cernerud [11] have identified variables such as age, gender, and technology acceptance, preferential choice between mobile/computer based, learning style, and previous experience of computers etc. as the predictive factors for the acceptance of technology among the students.

\section{Conclusion}

The present study marks students' ease to use as the dominant factor while making preferential choice between system based and mobile based learning. In terms of content building and resource collection for the course, system based learning is a convenient source as compared to mobile devices wherein the learner is limited to certain specific tasks only. He/she may not enjoy fully functional features available during the learning process. The focus of this study was limited to assess the various stakeholders' preferential choices regard to e-learning and m-learning. Their opinion on the nature of these technologies that could enhance face-to-face modes of interaction could have yielded better understanding on users' perception. How do the users interact with learning resources, their teachers and peers, and the way they follow through the available resources could also be very interesting in evaluating their needs and their concerns regarding their learning process.

It is very clear from the students' responses that they are very aware of the use of technological interventions and its impact on their learning process. They are well informed of the tools and are well prepared in using technology in a formal set up. Furthermore, they understand that the use of such alternate methods and tools of learning could impact their learning process very positively. Now filtering out the best suited study materials, interacting with their peers, teachers and ease of following their academic activities are such features that empower them to have a sense of control over their learning process. A teacher has become a mentor, a guide who can indirectly and conveniently monitor the students and engage them effectively into the learning process and in-turn save the teachers from burning out and enjoy their profession.

\section{Acknowledgements}

This researcher would first like to thank the participating students \& faculty members without whom the research couldn't become complete to obtain the outcomes for this research. The author extends thanks to the Ministry of Education in the Kingdom of Saudi Arabia and Northern Border University (NBU) for funding this Research Project which became success under its Deanship of E-learning \& Distance Learning. It was a great motivation for the author to find all possible support from the University Leadership that boosted morale of researcher to complete the project on time. 


\section{$7 \quad$ References}

[1] Allen, I. E. \& Seaman, J. "Class differences: online education in the United States". The Sloan Consortium, 2010. Retrieved November 28, 2012, from http://sloanconsortium.org/publications/survey/pdf/class_differences.pdf

[2] B. Holmes and J. Gardner. "E-learning: concepts and practice". London: Sage, 2006.

[3] Chancery, F.H. \& Islam, S.“Is Saudi Arabia ready for E-learning? - A Case Study”. 2008.

[4] F. Mikic and L. Anido. "Towards a Standard for Mobile ELearning". International Conference on Systems and International Conference on Mobile Communications and Learning Technologies, ICN/ICONS/MCL 2006. International Conference on Networking, 217-222, 2006.

[5] Fry, K. "E-Iearning Markets and Providers: some issues and prospects". Training and Education, 43(4), 233-239, 2001. https://doi.org/10.1108/EUM0000000005484

[6] Gamal. S., \& El aziz, Rasha. "The perception of students regarding E-learning implementation in Egyptian universities". The Third International Conference on Mobile, Hybrid, and On-line Learning (IARIA), 2011.

[7] Gartner. http://www.gartner.com/it/page.jsp?id=2153215, September 112013.

[8] Georgouli K., Skalkidis I., and Guerreiro P. "A Framework for Adopting LMS to Introduce e-Learning in a Traditional Course". Educational Technology \& Society, 11(2), 227240, 2008.

[9] Harasim, L., Hiltz, R., Teles, L., \& Turoff, M. "Learning networks: A field guide to teaching and learning online", Cambridge: MIT Press, 1995.

[10] Internet Usage in the Middle East, 2010, available at http://www. Internet worldstats.com/stats5.htm.

[11] Keller, C. \& Cernerud, L. "Students' perception of e-learning in universities education". $\begin{array}{lllll}\text { Journal of } & \text { Educational }\end{array}$ https://doi.org/10.1080/1358165020270105

[12] http://techcrunch.com/2013/05/29/mary-meeker-2013- internet-trends/, May 29.

[13] J. K. Njenga and L. C. H. Fourie. "The myths about E-learning in higher education". Br. J. Educ. Technol., 41 (2), 199-212, 2010. https://doi.org/10.1111/j.1467-8535.2008.00910.x

[14] J. Wu. "On Top of Tides (Chinese Edition)". Beijing: China Publishing House of Electronics Industry, January 82011.

[15] Jain K.K., Ngoh B.L. "Motivating Factors in e-learning - A Case study of UNITAR" April 25, 2015. Available from: http://www.studentaffairs.com/ejournal/Winter_2003/elearning. html, 2008.

[16] Keegan, D. "Theoretical principles of distance education". London: Rutledge falmer, 1993.

[17] "List of mobile software distribution platforms". http://en.wikipedia.org/wiki/List of digital distribution platforms for mobile devices, July 192013.

[18] Lorenzi, N. \& Riley, R. "Managing Change". J Am Med Inform Assoc. 7(2), 116 - 124, 2000. https://doi.org/10.1136/jamia.2000.0070116

[19] R. Lawler, Mary Meeker. "Internet Trends report". 2013.

[20] Revelle G., Reardon E., Green M. M., Betancourt J. and Kotler J. (2007). The use of mobile phones to support children's literacy learning. In Y. de Kort et al. (Eds.): PERSUASIVE 2007, LNCS 4744, 253-258, 2007.

[21] Rogers, E.M. "Diffusion of innovations ( $5^{\text {th }}$ ed.)". New York: The Free Press, 2003.

[22] Venkatesh, V., Morris, M.G., Davis, G.B., \& Davis, F.D. "User acceptance of information technology: Toward a unified view”. MIS Quarterly, 27 (3), 425-478, 2003. 
[23] S. Alexander. "E-learning developments and experiences, education and training". vol. 43, 240-248, 2001.

[24] S. Q. Feng. "Android software security and reversing engineering analysis (Chinese Edition)". Beijing: Posts and Telecom Press, 2013.

[25] Sekaran U. A Skill Building Approach. John-Wiley 7 sons, Inc. 2012

[26] Smith Jaggars, S. \& Bailey, T. "Effectiveness of fully online courses for college students: response to a department of education meta-analysis". New York: Community College Research Center, Teachers College, Columbia University. Retrieved November 28, 2012, from http://ccrc.tc.columbia.edu/Publication.asp?UID=796

[27] Yuan-Kai Wang. "Context awareness and adaptation in mobile learning". Proceeding of The Second IEEE International Workshop on Wireless and Mobile Technologies in Education (WMTE'2004).

[28] Z. Melicheríková \& A. Busikova. "Adaptive E-learning - A tool to overcome disadvantages of E-learning". IEEE 10th International Conference on Emerging eLearning Technologies Applications (ICETA), 263-266, 2012.

\section{Author}

Ahmed Majoon Alenezi is an Assistant Professor in faculty of Education \& Arts at Northern Border University, KSA. In addition, he is the Dean of Deanship of eLearning \& Distance education, Northern Border University, Saudi Arabia. He is associated as Editorial Advisory Board member in many international journals like European Journal of Advances in Engineering and Technology (EJAET), International Journal of Multidisciplinary Research and Modern Education (IJMRME), International Journal of Engineering technology \& Computer Research (IJETCR). He is an active member of Egyptian Society for Technology Education, Cairo, IEEE, and Society for Information Technology \& Teacher Education (SITE).

Article submitted 21 February 2017. Published as resubmitted by the author 15 April 2017.

\section{$9 \quad$ Appendix}

\begin{tabular}{|c|l|l|l|l|l|l|}
\hline \multicolumn{2}{|c|}{ Measure( Time Duration) } & $\begin{array}{c}\text { Strongly } \\
\text { Agree }\end{array}$ & Agree & Neutral & Disagree & $\begin{array}{c}\text { Strongly } \\
\text { Disagree }\end{array}$ \\
\hline $\mathbf{1}$ & $\begin{array}{l}\text { You access frequently e learn- } \\
\text { ing tools? }\end{array}$ & & & & & \\
\hline $\mathbf{2}$ & $\begin{array}{l}\text { You are always active on e- } \\
\text { learning tool for study purpose? }\end{array}$ & & & & & \\
\hline $\mathbf{3}$ & $\begin{array}{l}\text { You access frequently M- } \\
\text { learning tools? }\end{array}$ & & & & & \\
\hline $\mathbf{4}$ & $\begin{array}{l}\text { You are always active on m- } \\
\text { learning tool for study purpose? }\end{array}$ & & & & & \\
\hline
\end{tabular}


Paper-Checking on Preferential Choices of E-learning \& M-learning: A Case Study of Northern Border...

\begin{tabular}{|c|l|l|l|l|l|l|}
\hline \multicolumn{2}{|c|}{ Measure(User Satisfaction) } & $\begin{array}{c}\text { Strongly } \\
\text { Agree }\end{array}$ & Agree & Neutral & Disagree & $\begin{array}{c}\text { Strongly Disa- } \\
\text { gree }\end{array}$ \\
\hline $\mathbf{1}$ & $\begin{array}{l}\text { E leaning mode you are more } \\
\text { comfortable to make/give quiz- } \\
\text { zes }\end{array}$ & & & & \\
\hline $\mathbf{2}$ & $\begin{array}{l}\text { E learning mode you are read- } \\
\text { ing/creating Announcement }\end{array}$ & & & & & \\
\hline $\mathbf{3}$ & $\begin{array}{l}\text { Reading study content is more } \\
\text { easy in e learning mode }\end{array}$ & & & & & \\
\hline $\mathbf{4}$ & $\begin{array}{l}\text { E Learning is efficient. } \\
\mathbf{5}\end{array}$ & $\begin{array}{l}\text { The output is presented in a } \\
\text { useful manner in e learning }\end{array}$ & & & & \\
\hline $\mathbf{6}$ & $\begin{array}{l}\text { Are you satisfied with e learning } \\
\text { method as compared to m learn- } \\
\text { ing }\end{array}$ & & & & & \\
\hline $\mathbf{7}$ & $\begin{array}{l}\text { M leaning mode you are more } \\
\text { comfortable to make/give quiz- } \\
\text { zes }\end{array}$ & & & & & \\
\hline $\mathbf{8}$ & $\begin{array}{l}\text { M learning mode you are read- } \\
\text { ing/creating Announcement }\end{array}$ & & & & & \\
\hline $\mathbf{9}$ & $\begin{array}{l}\text { Reading study content is more } \\
\text { easy in m learning mode }\end{array}$ & & & & & \\
\hline $\mathbf{1 0}$ & $\begin{array}{l}\text { M Learning is efficient. } \\
\mathbf{1 1}\end{array}$ & $\begin{array}{l}\text { The output is presented in a } \\
\text { useful manner in m learning }\end{array}$ & & & & \\
\hline $\mathbf{1 2}$ & $\begin{array}{l}\text { Are you satisfied with m learning } \\
\text { ing as compared to e learn- } \\
\text { ing }\end{array}$ & & & & & \\
\hline
\end{tabular}

\begin{tabular}{|c|l|l|l|l|l|l|}
\hline \multicolumn{2}{|c|}{ Measure (User friendly) } & $\begin{array}{c}\text { Strongly } \\
\text { Agree }\end{array}$ & Agree & Neutral & Disagree & $\begin{array}{c}\text { Strongly } \\
\text { Disagree }\end{array}$ \\
\hline $\boldsymbol{1}$ & $\begin{array}{l}\text { E learning is mode is more user } \\
\text { friendly }\end{array}$ & & & & & \\
\hline 2 & $\begin{array}{l}\text { M learning is mode is more } \\
\text { user friendly }\end{array}$ & & & & & \\
\hline 3 & $\begin{array}{l}\text { M learning devices are easy to } \\
\text { carry }\end{array}$ & & & & & \\
\hline 4 & $\begin{array}{l}\text { E learning devices are easy to } \\
\text { carry }\end{array}$ & & & & & \\
\hline
\end{tabular}


Paper-Checking on Preferential Choices of E-learning \& M-learning: A Case Study of Northern Border..

\begin{tabular}{|c|l|l|l|l|l|l|}
\hline \multicolumn{2}{|c|}{ Measure (Connectivity) } & $\begin{array}{c}\text { Strongly } \\
\text { Agree }\end{array}$ & Agree & Neutral & Disagree & $\begin{array}{c}\text { Strongly } \\
\text { Disagree }\end{array}$ \\
\hline $\mathbf{I}$ & $\begin{array}{l}\text { E learning mode is convenient } \\
\text { to use anywhere }\end{array}$ & $\begin{array}{l}\text { E learning provides high speed } \\
\text { access to system }\end{array}$ & & & & \\
\hline $\mathbf{3}$ & $\begin{array}{l}\text { I can teach \& attend classes } \\
\text { through videoconferencing } \\
\text { anytime in e learning when I } \\
\text { am out of my classroom. }\end{array}$ & & & & & \\
\hline $\mathbf{4}$ & $\begin{array}{l}\text { M learning mode is convenient } \\
\text { to use anywhere }\end{array}$ & & & & & \\
\hline $\mathbf{5}$ & $\begin{array}{l}\text { M learning provides high speed } \\
\text { access to system. }\end{array}$ & & & & & \\
\hline $\mathbf{6}$ & $\begin{array}{l}\text { I can teach \& attend classes } \\
\text { through videoconferencing } \\
\text { anytime in m learning when I } \\
\text { am out of my classroom. }\end{array}$ & & & & & \\
\hline
\end{tabular}

\begin{tabular}{|c|c|c|c|c|c|c|}
\hline \multicolumn{2}{|c|}{$\begin{array}{c}\text { Measure (Benefits of E Learning \& } \\
\text { M learning) }\end{array}$} & $\begin{array}{l}\text { Strongly } \\
\text { Agree }\end{array}$ & Agree & Neutral & Disagree & $\begin{array}{l}\text { Strongly } \\
\text { Disagree }\end{array}$ \\
\hline 1 & $\begin{array}{l}\text { E Learning helps me to improve } \\
\text { my learning performance. }\end{array}$ & & & & & \\
\hline 2 & $\begin{array}{l}\text { Overall the impact of E learning } \\
\text { system is on learning has been } \\
\text { positive }\end{array}$ & & & & & \\
\hline 3 & $\begin{array}{l}\text { E learning helps the university } \\
\text { save cost related to teaching } \\
\text { and learning }\end{array}$ & & & & & \\
\hline 4 & $\begin{array}{l}\text { Learning through e learning is } \\
\text { easier. }\end{array}$ & & & & & \\
\hline 5 & $\begin{array}{l}\text { M Learning helps me to im- } \\
\text { prove my learning performance. }\end{array}$ & & & & & \\
\hline 6 & $\begin{array}{l}\text { Overall the impact of m learn- } \\
\text { ing system is on learning has } \\
\text { been positive out of my class- } \\
\text { room. }\end{array}$ & & & & & \\
\hline 7 & $\begin{array}{l}\text { M learning helps the university } \\
\text { save cost related to teaching } \\
\text { and learning }\end{array}$ & & & & & \\
\hline 8 & $\begin{array}{l}\text { Learning through } \mathrm{m} \text { learning is } \\
\text { easier. }\end{array}$ & & & & & \\
\hline
\end{tabular}

